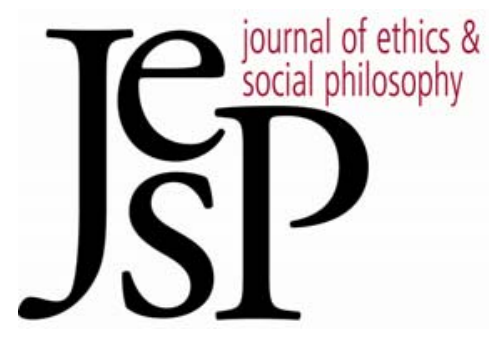

\title{
FIRST FORCE
}

BY WILLIAM A. EDMUNDSON

Journal of Ethics \& Social Philosophy

Vol. 1, No. 3| NOVEMBeR 2005

URL: WWW.JESP.ORG

COPYRIGHT (C) WILLIAM A. EDMUNDSON 2005 


\section{FIRST FORCE}

By William A. Edmundson

$\mathrm{I}$

s the very existence of government morally problematic? Is government morally problematic, that is, in a way that a "state of nature" is not? Many political philosophers have thought so. I will argue that they are wrong. If that seems too easy, I also will argue that the modern welfare state is no more problematic, morally, than a minimal, "nightwatchman" state. (If all of this seems too easy, I hope to convince you that it is not as easy as you might think.)

One vivid way of conveying the idea that government is prima facie wrongful is by employing a metaphor. Just as the gunman, who takes our money upon threat of violence, acts wrongfully, so also the state acts wrongfully by exacting its citizens' obedience by threatening punishment; the state is simply the gunman writ large. ${ }^{1}$ Compare the following cases.

\section{Case 1: Highway Robbery}

Gunman stops Traveler on the highway and demands, "Your money or your life!" Gunman's proposal is coercive and wrongful. Traveler surrenders his money. Gunman has wrongfully coerced Traveler.

\section{Case 2: Robbery Statute}

A state enacts a statute which provides that anyone convicted of highway robbery shall be punished for a term of not less than five and not more than 20 years. It is probably thought that the state coerces its citizens not to engage in highway robbery.

To say that an action is coercive is, normally anyway, to say that it is at least prima facie wrongful. Although the idea that government bears a moral taint could be expressed in other ways, I will focus on the belief that the state, and its law, is coercive. The state is like a gunman writ large, in short, because, and to the extent that, it is coercive in a way that is at least prima facie wrongful.

Our normal response to coercive threats, like the Gunman's behavior in case 1, is to condemn them unless some further facts in justification of such conduct are provided, e.g., that Traveler is bankrolling a terrorist organization and Gunman is acting to frustrate a terrorist plot that can be checked in no other way. Whether a sufficiently strong justification can be provided is a further question, upon which the Gunman bears some sort of burden of proof. ${ }^{2}$

Case 2 has seemed to many to be sufficiently analogous to case 1 to support the analogous claim of presumptive wrongfulness. State stands to citizen as Gunman stands to Traveler, that is to say, the state coerces its citizens and therefore a justification is demanded - a

\footnotetext{
1 "A penal statute declaring certain conduct to be an offence and specifying the punishment to which the offender is liable, may appear to be the gunman situation writ large...." H.L.A. Hart, The Concept of Law 6-7 (Oxford: Clarendon, 1961). I have explored cases 1-4 in greater detail elsewhere.

${ }^{2}$ Hans Oberdiek, "The Role of Sanctions and Coercion in Understanding Law and Legal Systems," 1975 American Journal of Jurisprudence 71, 80. Assigning the burden of proof to an opponent is a key move in what has been termed the "argument from ignorance." See Richard H. Gaskins, Burdens of Proof in Modern Discourse (New Haven: Yale University Press, 1992).
} 
special justification of a kind not needed if, for example, the state failed to enact such a statute or repealed it. ${ }^{3}$

But can anyone seriously argue that the state acts immorally, or contrary to a moral duty, by proposing to punish the highway robber? The answer must be no. But this in turn seems to commit us to saying that case 2 is not a case of prima facie wrongful conduct on the part of the state. ${ }^{4}$

Consider the following variation on case 1:

\section{Case 3: Tables Turned on the Gunman}

As in case 1 but, rather than comply with Gunman's demand, Traveler states that he, too, is armed and that he is prepared to defend himself and his wallet with deadly force if necessary.

Is Traveler's conduct toward Gunman even prima facie wrongful? Most of us would answer no.

One might suggest that case 2 is distinguishable from case 3 insofar as, in case 3 , coercion is absent only because the putative coercee has initiated the use of force. But case 3 can readily be redescribed to remove that feature, yet without disturbing the intuition that the Traveler has not acted even prima facie wrongfully. Replace the Gunman's threatening conduct with the Traveler's generalized anxiety about the possibility of its occurring, so that Traveler displays a general preparedness to use force not to a manifest threat, but to a world which he supposes to harbor such threats. Prima facie wrongful? Again, most would answer no. But if not in case 3, then it is not true in case 2 (Robbery Statute) either. We are impelled toward what many will see as the surprising conclusion that the state is not intrinsically more coercive - and therefore, to that extent, no more morally objectionable - than a state of nature.

So far, what I have said is congenial to the Grotean/Hobbesian/Lockean reconstruction of the legitimacy of the state. There is an important limitation to this line of thinking, which can be put as a kind of pre-emptive objection to generalizing this line to encompass the full range of powers assumed by modern welfare states. The objection goes like this: "What makes case 3 (Tables Turned) not a case of prima facie wrongful coercion is the fact that Traveler's threat is a threat to respond to first force. It does not matter whether or not Traveler's threat comes first; what matters is that Traveler's threatened use of force will not precede the use of force against him. It is the use, and the threatened use, of first force that are wrongful, not the threat to retaliate against first force." The objection now takes aim: "The state is traveler writ large, rather than gunman writ large, only in those cases in which its threats are threats to retaliate against first force against its citizens. At best, what has been shown is that a 'nightwatchman' state is not necessarily more objectionable, morally, than a state of nature in which individuals exercise rights of self-defense and of defense of others. But as soon as the state arrogates further powers - and presumes to tax to support those powers - it ceases to be traveler writ large and reveals itself as gunman writ large." If the objection is sound, it cuts off the possibility of a Lockean defense of the modern welfare state.

The libertarian point can be put this way:

${ }^{3}$ Vinit Haksar, "Coercive Proposals" 4 Political Theory 65, 68 (1976).

${ }^{4}$ Haksar, "Coercive Proposals" at 73 \& 74 n.11. 


\section{Case $4 \quad$ Robin Hood and the Levite}

An Innocent has been gravely injured and lies helpless on the road. A Levite happens by. The Levite is capable of rendering necessary monetary and other assistance to Innocent, but intends to do nothing. Robin Hood appears and threatens to use force against Levite to compel Levite to assist Innocent. Robin Hood's proposal is coercive and at least prima facie wrongful. Levite renders assistance. Prima facie, at least, Robin Hood has wrongfully coerced Levite.

Robin Hood's threat in Case 4 crucially differs from Traveler's threat in case 3 , in that Robin Hood threatens first force, while Traveler threatens second force. Therefore the state, when it acts as Robin Hood acts, employs first, not second force, and is a wrongful coercer. The coercion may be justified, but it ever retains its moral taint. The No First Force principle, which many find intuitively attractive, seems to lend itself to - even to dictate - a moral distinction between the nightwatchman state and the welfare state.

But not so fast. Consider the following example:

\section{Case $5 \quad$ Initial Appropriation}

Farmer gathers apple seeds, which he then plants in the ground. When trees grow and begin to bear fruit, he encloses the area and tells Gatherer to stay out or be knocked in the head. Gatherer approaches the trees but Farmer pushes him away.

Who is the first forcer here? Rousseau put the matter not quite strongly enough when he wrote: "The first person who, having enclosed a plot of land, took it into his head to say this is mine and found people simple enough to believe him, was the true founder of civil society." 5

Pace Rousseau, the "true founder of civil society" could not have relied so upon the simplicity of strangers. Laying claim to property involves more than merely gulling the gullible; it means being manifestly prepared to back up the claim with force when challenged by the not so simple. But those whom the first proprietor threatens and, if necessary, forces, need not themselves have first used or threatened force. Gatherer may, for example, readily eat the apples of the tree Farmer has cultivated without using or threatening force against him. If his orchard is extensive enough, Gatherer won't even have to be sneaky about it.

Jeremy Waldron has pointed out that the No First Force maxim - originally Kant's ${ }^{6}-$ has got to be relaxed if any institution of private property is going to be morally permissible. The idea is simple: property begins not in nature but in acts of appropriation, which in turn involve the use and threatened use of force against persons who might carry off, tread upon or consume the thing that has now become property. Therefore, if Waldron is right (as I think he is), No First Force has to be qualified if the institution of private property is, morally, to get off the ground. The trick for the libertarian is going to be relaxing No First Force just

5 J.-J. Rousseau, "Discourse on the Origin of Inequality" in Donald A. Cress, trans., The Basic Political Writings 60 (Indianapolis: Hackett, 1987). In the original: "Le premier qui ayant enclos terrain s'avisa de dire, ceci est à moi, et trouva des gens assez simples pour le croire, fut le vrai fondateur de la société civile."

${ }^{6}$ Immanuel Kant, Metaphysical Elements of Justice 28-34 John Ladd, trans., 2d ed. (Indianapolis: Hackett, 1999). 
enough to get private property going, but not by so much that compulsory redistribution by the state loses its coercive character. This is the libertarian's dilemma: stick with a strict No First Force maxim (disallowing both appropriation and forceful dispossession), or qualify the No First Force maxim (running the risk that the qualifications may, if principled, turn out to permit both appropriation and redistributive taxation).

The point can be put differently. No First Force can be a workable principle only if there is a way to identify more or less precisely what the relevant moral background is against which a threat or use of force stands out as a first departure. Libertarians and others on the political right would like this background to consist of the legal institutions and patterns of property holding pretty much as we find them at the moment (and they are not alone in this). Never mind the tormented history underneath this pattern. But it is important that this background not include redistributive taxation because, if it did, that scheme of taxation could not be criticized as a systematized application of first force, hence as coercive. It would have to be criticized on some other ground, and once it were granted that redistributive taxation is not coercive in the invidious, gunman writ large sense, those other grounds might not seem quite as compelling.

Locke's theory of property suggests a revised No First Force maxim: "No first force, except to establish property by the admixture of labor, while leaving enough and as good for others, or to defend property so established and received in fair transfer." The "Lockean Proviso" that "enough and as good" be left for others to use or appropriate is a necessary palliative, but what warrants restricting it to the initial appropriation? ${ }^{7}$ Why, in other words, should property received in transfer have the benefit of the revised maxim? Surely the defender of an inherited monopoly is as suspect as any first appropriator who violates the Lockean proviso at the instant of original appropriation. So, a second revision will go: "No first force, except to defend property established by admixture of labor, or to defend property received in fair transfer - subject always to the proviso that enough and as good be left for others."

The doubly revised No First Force maxim will not please those who have set their faces against any "patterned" principle of distribution. The present maxim applies the Lockean Proviso not only to first appropriation, but also all along the line. No owner's effort to defend her property will be deemed a defense against first force unless that holding currently satisfies the proviso. It is no defense to say, "there was enough and as good when the world was new, too bad you weren't around then." There must be enough and as good for everyone at all times. ${ }^{8}$ Extending the Lockean Proviso to transfers in the way proposed is entirely distinct from insisting that unjust initial appropriation forever taints title. If an unjust initial appropriation happens to sort itself out over time in such a way that "enough and as good" becomes available to all, there may indeed be no good moral case for corrective redistribution.

\footnotetext{
${ }^{7}$ John Locke, The Second Treatise of Government 17, Thomas P.Peardon, ed. (Indianapolis: Bobbs-Merrill, 1952). There are actually two provisos - the second being that no more may be appropriated than may be used before spoilage (id. at 19) - but for ease of exposition I will speak of the Lockean Proviso. For a different reading of Locke, see Jeremy Waldron, "Enough and as Good Left for Others,” Philosophical Quarterly 29 (1979).

${ }^{8}$ Assuming that no particular point in history has any special claim to be fixed as a baseline against which later distributions are to be measured. Reasons of salience and convenience that suffice to make the birth of Christ a universal marker for measuring the passage of years aren't available in the moral domain - hence, one aspect of the bootlessness of most discussions of reparations to exploited groups.
} 
Can the libertarian simply reject any extension of the Lockean Proviso to transfers? Such a rejection would bring in its train some wildly counterintuitive consequences. Robert Nozick confronted, for example, the possibility that person $A$ might become landlocked by the transfer of all surrounding lands to her neighbor $B .{ }^{9}$ Assume that the surrounding parcels severally had been justly appropriated, and that all subsequent transfers were in compliance with rules of just transfer. Assume further no ill motive on $B$ 's part - it just happens that $B$ now has what is in effect a right to confine $A$. Nozick impishly bites the bullet, suggesting that $A$ might arrange to be extracted by helicopter. The common law long ago adopted the sensible solution, holding that an "easement of necessity" arises in favor of $A$, permitting him to come and go across B's land. Nozick's hypothetical is simply a colorful exemplar of a sizeable class of cases; and the only palatable, principled way to treat them is one that is consistent with the extension of Locke's Proviso to transfers.

This is not to say that in circumstances of scarcity everything is up for grabs. There should be moral rights to property, enforceable ones, but those rights will be counterpoised by moral rights to expropriate in conditions of dire need. How are these to be reconciled, and who is entitled to enforce the reconciling result? No individual "natural executive right" will make any better sense here than in the case of punishment. The right to enforce the contours of private property is a social, not an individual, natural moral right for the very same reasons that Nozick urged against Locke's supposed, individually held right to punish wrongdoing. If in the state of nature each person individually held a natural executive right to punish wrongdoing, the harshness and inconsistency that would ensue must strike us as absurd. But ascertaining the property rights as between a present possessor and a needy latecomer can no more be left to the determination of the parties, than the just measure of, say, a pound of flesh could properly be left to the sole determination either of a Shylock or an Antonio.

Given the inescapable contingency into which Locke's Proviso casts the right of property in any held thing throughout its career, those who forcefully defend their holdings are always in the company of those who presume to punish assaults, rather than the company of those who merely resist them. ${ }^{10}$ Lacking any such individual executive right, forceful defenders of their property - unlike forceful defenders of themselves and others - will in such circumstances be first forcers, coercers. Whether their actions are morally defensible all things considered will have to depend upon some other line of argument than that suggested by Locke and Kant. But the state that acts to see to it that the Lockean Proviso is satisfied need not be cast as users of first force, or as coercers. All that needs to be supposed is that society's right to determine and enforce the boundaries of property has been assigned, by whatever means, to the state (and if not to the state, to whom?) Given the gross maladaption of resources to needs that we find in the world, the modern welfare state is no more a coercive "first forcer" than the Traveler in case 2. Granted, it may also be foolish, mistaken, wasteful, patronizing and sclerotic, but those are other faults.

Waldron's strategy for mounting a Locke-and-Kant-friendly defense of the welfare state goes like this: accept the No First Force maxim, but replace the usual "image of charity" as charitable action - and of state-mandated redistribution as action compelled by first force -

${ }^{9}$ Robert Nozick, Anarchy, State and Utopia 134-42 (New York: Basic Books, 1974).

10 At least, so long as we exempt the human body from the reach of the Lockean Proviso. Locke appears to have held that we have property in our labor, and what we mix it with, but not in our bodies, strictly speaking, because we are not free to destroy or alienate our bodies. See John Locke, supra note 8, at 15-16, 27. 
with an image of charity as forbearance, and of state-mandated charity (redistribution) as second force designed to preempt first force by owners against needy self-helpers. A window of opportunity for legitimating the welfare state is opened by subjecting the presumptively legitimate property rights regime to the following principle:

(P) Nobody ever should be permitted to use force to prevent another man from satisfying his very basic needs in circumstances in which there seems to be no other way of satisfying them. ${ }^{11}$

Waldron offers this example:

\section{Case 6 Mountain Cabin}

The owner of a remote and well-provisioned cabin who discovers needy intruders helping themselves to his soup is not permitted to expel them into the blizzard nor to rip the spoons from their hands. The owner's force is first force, not second.

Whether the owner would be entitled to use second force to repel an impending but incomplete intrusion is a question that suggests itself right away. But Waldron finesses it by directing the state to pursue a strategy of minimizing needs that might be thought to justify such intrusions - a strategy which, coordinately, would assure owners that intruders are not needy, but greedy. What rights of self-help resistance owners possess against the now presumptively greedy expropriators is not a subject Waldron broaches.

Waldron is confessedly modest about how much of the welfare state Principle $(\mathrm{P})$ is in fact able to rescue from classical liberalism's No First Force objection. Left out of account are: the legitimacy of "North/South" redistribution on an international scale; the legitimacy of compelled provision of services as opposed to goods and cash; and the legitimacy of taxation to provide aid reaching beyond "very basic" needs. And these omissions come on top of the artificiality of construing a refusal to submit to redistributive taxation as an application of first force against the needy.

I think a better strategy than Waldron's is to apply earlier pressure to those who want to maintain both No First Force and a system of private property. Waldron's strategy simply assumes that some straightforward and principled qualification of No First Force will permit the establishment and maintenance of the basic structure of private property. Room for a welfare state is then to be carved out of this structure by invoking Principle (P) to anchor the (strained) assimilation of redistributive taxation to second-force resistance to impermissible first-force self-help by stingy owners against needy but peaceable encroachers. Having granted so much to the libertarian, Waldron's defense of the welfare state consists of a rather circuitous taking back, by which depressingly little is actually regained.

The alternative strategy I propose has four stages. At the first stage, it challenges the opponent of the welfare state to come forward with his Principle, call it $\left(\mathrm{P}^{*}\right)$, which will restate and qualify No First Force in a way that permits initial appropriation. At the second stage, my strategy will scrutinize ( $\left.\mathrm{P}^{*}\right)$ to ascertain its position on whether Locke's Proviso applies only to initial acquisition or, in the alternative, "all the way down." (I will assume without argument that Locke's Proviso is a necessary part of any plausible theory of appropriation though Kant seems to have thought that first appropriators might legitimately take whatever they could hold on to. ${ }^{12}$ ) The hope is to show, at the third stage, that Locke's Proviso cannot

${ }^{11}$ Jeremy Waldron, Liberal Rights 240-41 (Cambridge: Cambridge University Press, 1993). 
be limited to initial acquisition for the very reasons that it cannot be omitted from any theory of property, much less from one to be reconciled with No First Force. At the fourth, and I hope triumphantly concluding, stage, it should be possible to show that $\left(\mathrm{P}^{*}\right)$ leaves ample room for all manner of redistributive institutions, including those transnational, service and supra-subsistence sorts which Waldron regretfully failed to bring into his account.

The strategy I propose is not original with me - G.A. Cohen and others ${ }^{13}$ have worked it out much farther than I have - and I will not pursue it further here. Rather, I want to address a familiar concern well expressed by my colleague Steven Rieber:

One thing that bothers me about most of the philosophical discussion of distributive justice is that it ignores most of the hard and important questions. Of course I agree in the abstract that a system of distribution needs to leave "enough" for the have-nots. But only in the abstract. In the real world there are all kinds of complicating factors. Should the have-nots have to work for their entitlements? What if they refuse to work? What if they more or less can't work because of their drug or alcohol problems? Presumably it depends at least in part on the degree to which they are responsible for these problems in the first place.... Most of this country's poor are children. How much is the government responsible for their plight, and how much are their parents - who perhaps should not have borne them in the first place if they were unable to provide for them? This raises a whole other nest of important issues. Political philosophers tend to focus on the extent of the state's duties to the poor. A good question, but there is another one, intimately related, which gets ignored: What are the state's rights over the poor? ${ }^{14}$

Many will find any reference to "rights over the poor" to be chilling. Let me suggest another case that may help illuminate this reaction.

\section{Case $7 \quad$ Vincent v. Lake Erie Transportation Co.}

To take shelter from a tempest, innocent Boatowner moors his boat against equally innocent Dockowner's dock. The dock is damaged, and Dockowner demands compensation from Boatowner. ${ }^{15}$

Suppose we vary the Vincent facts slightly. Suppose the Dockowner had been present on the dock and had demanded that the Boatowner pay an enormous sum for the privilege of docking. Even if the Boatowner agreed to the demand, we would balk at the idea that the Dockowner might thereby have gained a "right over" the Boatowner to that huge payment. The demand was coercive. But now suppose that the Dockowner had merely demanded compensation for any actual losses caused by the docking. I think we may be torn between the idea that the Dockowner's demand is still coercive, because he has no right to refuse permission to the Boatowner in this emergency, and the contrary idea that the demand is not coercive, because the Boatowner's right to take emergency shelter does not entail a further

${ }^{12}$ See Immanuel Kant, supra note 7, at 64 ("It is as though the land itself said to him, If you cannot protect me, you cannot command [govern] me.").

${ }^{13}$ G.A. Cohen, "Capitalism, Freedom, and the Proletariat,” in D. Miller, ed. Liberty (1991, Oxford: Oxford University Press) and more recently Liam Murphy and Thomas Nagel, The Myth of Ownership: Taxes and Justice (Oxford: Oxford University Press 2004).

14 Private correspondence.

15124 N.W. 221 (Minn. 1910). 
right to free shelter. An appeal to property rights will not settle anything, for the contour of those rights is precisely the issue.

Work requirements imposed by the state as a condition of welfare payments raise this very question. If dire need in itself reshapes property, then resources sufficient to relieve dire need simply become the property of the needy, and any attempt to place conditions upon access to those resources is coercive. If dire need does not have such moral power as this, then the provider of those resources may indeed insist upon conditions.

I am not sure how to decide the issue even in this artificially simplified form (as Rieber notes, things can get messy; what if the Boatowner in Vincent might have avoided the storm but for too much champagne?). To conclude, I will make two points. The first is that the moral power of need to reshape property diminishes as the need moves away from the basic and urgent - food, shelter, a place to relieve the bladder and bowels - and toward the less basic and urgent - such as interesting food and commodious, conveniently located shelter. There is room for controversy here, too: Is education basic? Are the "social bases of selfrespect" basic? ${ }^{16}$ But the idea that support above some social minimum is properly subject to conditions and requirements should not be shocking.

The second point is that even where conditions are permissible to impose, certain kinds of condition may still be odious - for example, conditioning supra-minimal assistance upon sterilization. To approximate what I think is the operative principle, conditions that express contempt for the needy are not proper ones. Work requirements are not contemptuous because the majority, whose taxes pay for assistance, value work. Contraception requirements, in contrast, would be contemptuous if the message they sent were that there should be no more of this sort of person and, by implication, there should never have been this person. Maximum-term-of-eligibility conditions of the kind in force now in the United States are contemptuous because the message they send is, roughly, "If you can't get it together in three years then you should die in a ditch." When the U.S. economy suffers its next bad run of three years, this last point may become even more obvious.

I hope to have established two main points. The first is that the "first force" metaphor supplies no nourishment unless mixed with something more substantial. At the very least, what the occasion demands is a more complete account of the moral baseline than what the familiar gestures toward "the state of nature" provide. The second is that, until such an account has been worked out, there is no reason to assume that the state is more liable to be a first forcer than private persons, individually or collectively. Because this is so, there as yet is no good reason to regard the state as laboring under any special burden of moral justification, or as glaring out from beneath any special moral cloud.

William A. Edmundson

Georgia State University

Law and Philosophy

${ }^{16}$ The phrase is John Rawls's, in A Theory of Justice 62 (Cambridge, Mass.: Harvard University Press, 1971). 